\author{
Multidisciplinary \\ SCIENTIFIC JOURNAL OF \\ MARITIME RESEARCH
}

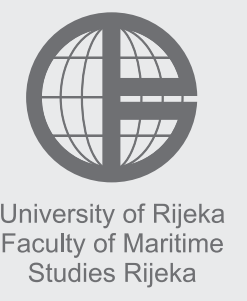

Multidisciplinarni

znanstveni časopis

POMORSTVO

\title{
Institutional Modelling of Integrated PPT System in Urban Agglomerations
}

\author{
Željko Smojver ${ }^{1}$, Hrvoje Baričević ${ }^{2}$ Donald Schiozzi ${ }^{3}$ \\ ${ }^{1}$ Rijeka Plus d.o.o., Školjić 15, 51000 Rijeka, Croatia, e-mail: zeljko.smojver@rijeka-plus.hr \\ ${ }^{2}$ University of Rijeka, Faculty of Maritime Studies, Studentska 2, 51000 Rijeka, Croatia, e-mail: hrvoje@pfri.hr \\ ${ }^{3}$ Port Authority Rovinj, Coast/Waterfront Aldo Rismondo 2, 52210 Rovinj, Croatia, e-mail: donald@port-rovinj.hr
}

\section{ABSTRACT}

Urban agglomerations (centres with gravitating settlements in the suburbs) are examples of overpopulated urban structure with almost permanent peak load. Selection of public transport is the fundamental issue in planning the expansion of the existing one, or in constructing a new form of urban public transport system. Achieving a higher level of using mass public transport can also be inspired by building intermodal terminals (e.g. bus-train/urban railways/-car). However, apart from the urban railway, funicular, bicycle subsystem and maritime transport should be included as alternative public transport modalities as well. According to the problem described in this scientific paper, the suggested model is that of integration of all forms of public passenger service with a unique organisation, unified payment collection, integrated timetable, all included into a unique information system. The results of research in this paper indicate that the first step of integration of the public passenger transportation implies founding regional transport administration.
\end{abstract}

\section{ARTICLE INFO}

Review article

Received 5 May 2018

Accepted 24 May 2018

Key words:

Urban agglomeration

Transport system

Passenger

\section{Introduction}

In practice, the public transport system consists of several transport systems that satisfy the passenger transport demand to greater or lesser extent, with higher or lower level of satisfaction of the service users. The most common urban public transport systems in small or mediumsized towns consist of buses and rail transport systems. Each of those transport systems achieves its mission with a certain level of quality, transport abilities, infrastructure and superstructure, organization and cost-effectiveness. The initiative for integration of urban public transport is initiated by relevant city transporters, and county and regional transporters from the reference area of operation, if needed. The overall understanding of the urban public transport strategy should result in comprehensive urban planning which may expand, if necessary, to county (regional) integral planning, based, of course, on scientific grounds. The significant component of the so-called total mobility is integral planning or general public transport plan, including all forms of public transport, as well as the so called modal SPLIT. The objective of this research is to create a new, original model for the integration of public passenger transport service, which has no model in communal structures of other Croatian cities.

\section{Proposal for Institutional Solution}

By analysing the public utility system, relationship was determined among public utility companies, as well as compatibility between the company providing public utility services and the company providing maintenance of roads and public surfaces, organizing parking and relocating of vehicles. With the goal of further checking compatibility of services of the two companies mentioned above, their services were divided into commercial and public utility, and were analysed separately, as displayed on Image 1.

As is clear from the previous chart, high level of connection and compatibility were proven between public utility services of urban public traffic, and traffic planning and design and traffic regulation and management of com- 


\begin{tabular}{|c|c|c|}
\hline Public utility company for public passenger transport & & $\begin{array}{l}\text { Company providing maintenance of roads and public } \\
\text { surfaces, organizing parking and relocating of vehicles }\end{array}$ \\
\hline Public utility services & & Public utility services \\
\hline - Urban public transport services & Compatible services & $\begin{array}{l}\text { - Planning and designing traffic } \\
\text { - Traffic regulation and management } \\
\text { - Traffic light maintenance } \\
\text { - Squares and staircases maintenance } \\
\text { - Traffic-related interventions } \\
\text { - Road maintenance }\end{array}$ \\
\hline Commercial services & & Commercial services \\
\hline $\begin{array}{l}\text { - Contracted and occasional transport } \\
\text { - Advertising services } \\
\text { - Various rentals (offices, space, parking) } \\
\text { - Bike rental }\end{array}$ & Commercial services & $\begin{array}{l}\text { - Relocating illegally parked vehicles } \\
\text { - Parking control and fee collection } \\
\text { - Rental of business premises } \\
\text { - Rental of traffic exercise areas }\end{array}$ \\
\hline
\end{tabular}

Image 1 Comparison of the properties of the public utility company for passenger transport and the road maintenance company

Source: AT Kearney: Analiza poslovanja i podizanje razine usluge gradskog prijevoza i prometa (Business Operation Analysis and Improving the Level of Urban Transport and Traffic Services), Rijeka, 27 June 2014

panies for road maintenance. Great synergy potential lies in the background of the two protagonists, such as development activities of a company planning and defining the city traffic, and enabling the public utility company for public passenger transport to provide higher level of urban public transport services. Optimising the public passenger transport system is a current issue for several reasons: increasing demands for transport, avoiding transport system isolation, inefficiency and disintegration, lack of coordination of individual forms of transport, large investment into the traffic system, protection of the environment and increasing IT possibilities. Furthermore, services of the company providing maintenance of roads and public surfaces enable the public utility company to optimize routes, which may eventually result in increased efficiency, expressing positive effect for both sides.

The new proposal for organizing city companies is defined by comparison with top European practices in organizing urban transport and the structure of city companies. The proposed concept is based on separating commercial and public utility activities from the companies mentioned above, and centralisation of the supporting functions of both companies. The new organisation shall enable the specialised companies to group public utility and commercial activities, as well as to centralise the supporting functions, which shall enable the increase of productivity, improve the quality of services and create possibilities of improvement in the future. The main advantages that the new organisation model will enable are the increase of profit, along with improvement of the quality of services and business efficiency, at lower operative costs. The said change does not mean new hiring or firing of workers. It means that the new organisation shall be filled by available staff, and expertise and knowledge of such staff shall be utilised better due to the new structure.

\section{Structure of the New Organisation}

\subsection{Extracting Supporting Functions From the Public Utility Company for Public Passenger Transport}

Centralising the supporting functions generates savings in procurement and other operative expenses, and eliminates double work. Furthermore, it enables improvement of the quality of services and achievement of better performance. Joint support functions are focused on integration of knowledge and competences resulting from specialisation of employees in the process organisation. The supporting functions centralisation effects are simplification of tasks, increase of speed and efficiency of operation, quicker and easier connection of new companies to the joint system of supporting functions and accumulation of "know-hows". Greater productivity and more employees working on the same function improve utility of resources. The results of centralisation are savings i.e. cutting the costs, freed investment potential and higher level of services for users.

Business activities included in the joint company are strategic development, finances with accounting and controlling, procurement and stock management, and joint departments (general, legal affairs and human resources, occupational safety, public relations and IT support). The departments and the entire organisational structure of the new company are presented in the Image 2.

Activities of the strategic development and projects department comprise of initiating all development projects, organizing and preparing studies and reports, as well as medium- and long-term development plans and programmes, evaluating the value of the works and equipment, participating in operation of established teams when drawing up project documentation necessary for realisation of individual designs and participating in plan- 


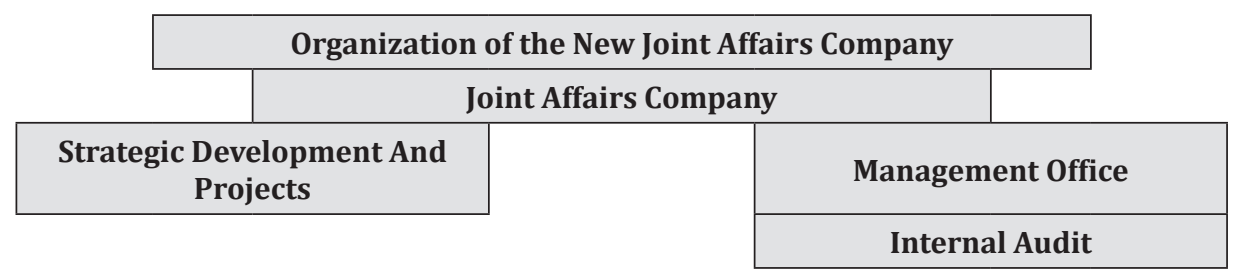

\begin{tabular}{|c|c|c|c|c|c|c|}
\hline \multicolumn{2}{|c|}{ Joint Departments } & \multicolumn{2}{|c|}{$\begin{array}{c}\text { Finances and Controlling } \\
\text { Department }\end{array}$} & \multicolumn{3}{|c|}{ Procurement Department } \\
\hline & & \multirow[b]{2}{*}{$\begin{array}{l}\text { Accounting } \\
\text { Department }\end{array}$} & Insurance Group & & & \\
\hline & & & $\begin{array}{c}\text { Finance } \\
\text { Department }\end{array}$ & $\begin{array}{c}\text { Stock } \\
\text { Management } \\
\text { Department }\end{array}$ & $\begin{array}{c}\text { Public } \\
\text { Procurement } \\
\text { Department }\end{array}$ & $\begin{array}{c}\text { Operative } \\
\text { Procurement } \\
\text { Department }\end{array}$ \\
\hline $\begin{array}{l}\text { IT Support } \\
\text { Group }\end{array}$ & PR & $\begin{array}{l}\text { Controlling } \\
\text { Group }\end{array}$ & $\begin{array}{c}\text { Financial } \\
\text { Operations Group }\end{array}$ & $\begin{array}{c}\text { Spare Parts } \\
\text { and other } \\
\text { Consummables } \\
\text { Group }\end{array}$ & & \\
\hline $\begin{array}{l}\text { Legal Affairs } \\
\text { Group }\end{array}$ & $\begin{array}{c}\text { General } \\
\text { Affairs and } \\
\text { Maintenance }\end{array}$ & $\begin{array}{l}\text { Accounting } \\
\text { Group }\end{array}$ & Cash Register & $\begin{array}{c}\text { Fuel and } \\
\text { Lubrication } \\
\text { Group }\end{array}$ & & \\
\hline $\begin{array}{l}\text { Human } \\
\text { Resources } \\
\text { Group }\end{array}$ & $\begin{array}{l}\text { Occupational } \\
\text { Safety Group }\end{array}$ & Payment Group & & & & \\
\hline
\end{tabular}

Image 2 Organisational structure of the new company for joint affairs

Source: The Boston Consulting Group Servicing LLC: Završni elaborat projekta: "Izdvajanje komercijalne djelatnosti i potpornih funkcija iz KD Autotrolej", (Final study of the project: "Extracting commercial activities and supporting functions from the public utility company Autotrolej”) Rijeka, 5 December 2014

ning phases and monitoring the course of realising investment projects within the established teams. Extracting the support functions improves utilization of human knowledge and expertise.

Legal affairs, human resources, general affairs and public relations departments are also extracted from the public utility company for public passenger transport, and are located in the joint affairs company within the Joint Departments. The IT Group was also extracted there, from the former Finance Department. Joint departments shall deal with management and coordination of general and legal affairs, HR activities, occupational safety and IT support, by planning the needs for human resources, realising the workers' rights via collective agreements, providing legal assistance to all companies, providing IT assistance to the users, PR, implementing laws and regulations concerning occupational safety, environmental protection and fire protection, and monitoring the implementation of the same, as well as by organizing, protecting and supervising objects and assets.

Apart from the IT Group, finances department of the public utility company for public passenger transport was also extracted to the Business Systems within the Financing and Accounting Department. Activities of the financing and accounting department consolidate business coordination and preparing of all accounting data for au- dits, management of insurance assets, persons and goods, implementation of controlling in all organisation units, closing financial frameworks of all development and investment projects in cooperation with Customer Services, preparing investment studies on feasibility of investment and financial analysis, preparing procedures for managing finances, accounting and controlling, as well as preparing accounting policies.

A part of the commercial department of the said public utility company, in charge of procurement and stock management, is extracted into the new company within the Procurement Department. The procurement activities include management and coordination of sales activities, marketing activities, procurement of goods, works and services, making sure that procurement is performed in compliance with the procurement plan within the framework of financial assets, defining and preparing technical specifications pursuant to historic data for all users, participation in preparing procurement and sales contracts, and direct participation in stock management.

\subsection{Extracting Commercial Activities From the Public Utility Company for Public Passenger Transport}

Commercial activity is also extracted into a separate company, while the public utility company for public pas- 

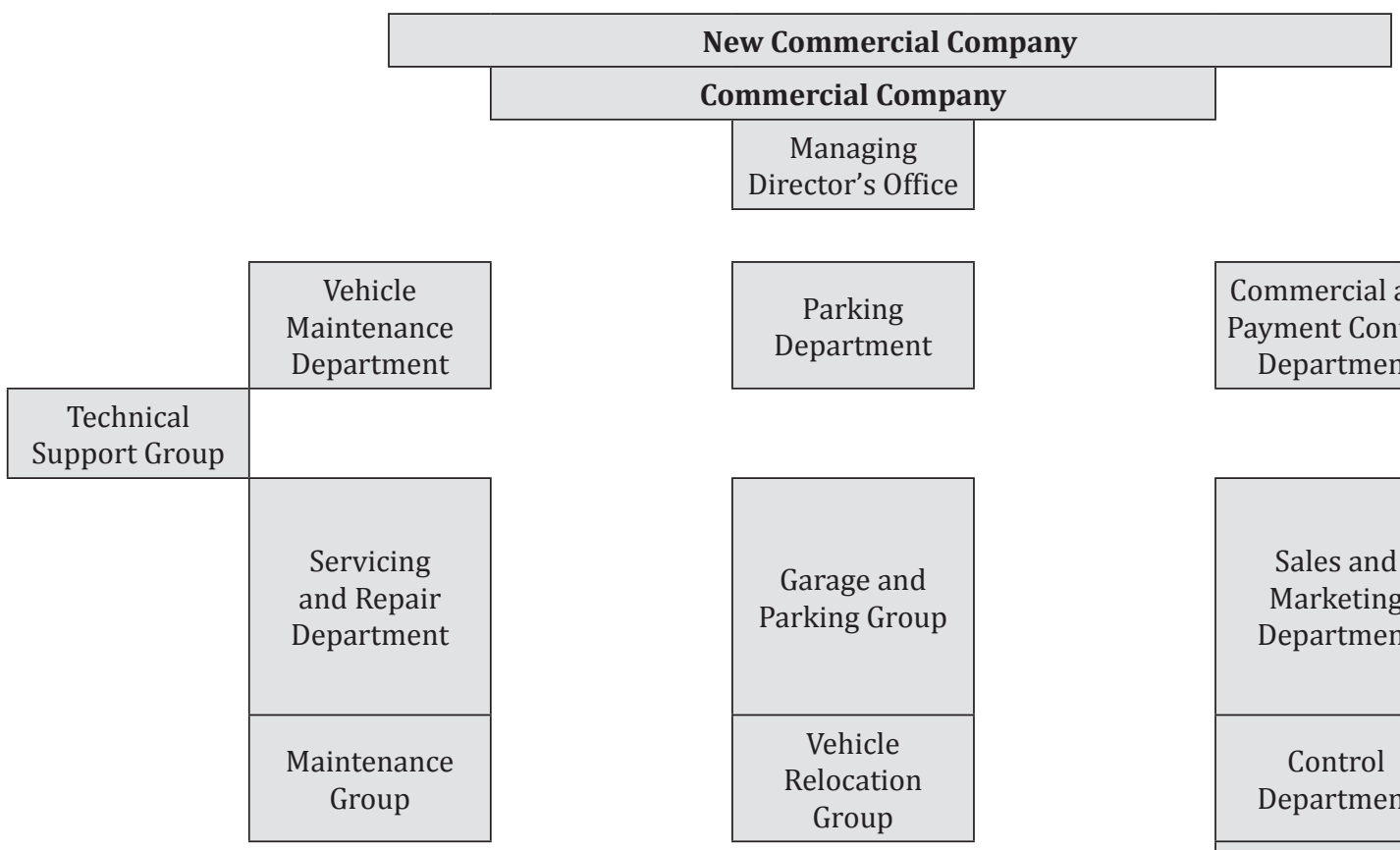

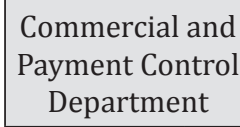

Department

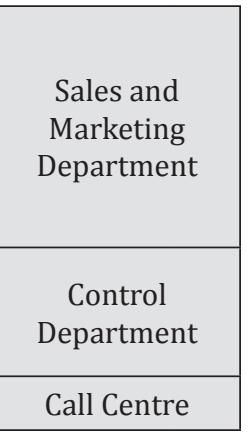

Selling Add Space Selling Transport Space Selling Vehicle Maintenance Services

Image 3 Organisational structure of the new commercial company

Source: The Boston Consulting Group Servicing LLC: Završni elaborat projekta: “Izdvajanje komercijalne djelatnosti i potpornih funkcija iz KD Autotrolej”, (Final study of the project: “Extracting commercial activities and supporting functions from the public utility company Autotrolej”) Rijeka, 5 December 2014

senger transport and the company providing maintenance of roads and public surfaces, organizing parking and relocating of vehicles shall keep its public utility activities and legal personality. The new organisation is of special importance since it enables unique implementation of strategies, greater quality and efficiency, and more efficient commercial operation. Furthermore, one of the motivators to form a new commercial company is also adherence to EU regulations and improvement of business efficiency. The Image 3 displays organizational structure of the socalled newly founded departments and their activities within the new company.

With the goal of better understanding the business processes and activities within the Maintenance Department and its connection to the Traffic Department of the public utility company for public passenger transport, the process of vehicle control and maintenance was analysed and it was concluded that a part of the Maintenance Department dealing with maintenance quality shall remain within the public utility company. Furthermore, a part referring to vehicle repairs was transferred into the new commercial company, which establishes the competency centre for potential maintenance of all vehicles in the public utility sector. This created organisational and resource preconditions for establishing a competency centre for maintenance of all vehicles in the public utility sector and local self-government units of the said Company, as well as for generating additional income through provision of services on the market.
Activities of the vehicle maintenance department include preventive and corrective maintenance of vehicles, plants and machines, defining and preparing technical specifications from the scope of responsibility for procurement of goods, works and services in tenders, in cooperation with the Commercial and payment Control Department, ensuring the users' planned technical roadworthiness of vehicles. Within the new commercial company, a Parking Department was formed, comprising commercial activities of the Parking Department of the company providing maintenance of roads and public surfaces, organizing parking and relocating vehicles.

Furthermore, the Sales and marketing department was transferred into the new commercial company providing to the public utility company for public passenger transport the services of selling tickets, available bus capacities and advertising on and in buses. The Sales and Marketing Department is located within the Commercial and Payment Control Department. Ticket Control Department, which was previously within the Legal Affairs, Human Resources and General Affairs Department, was also transferred to the Commercial and Payment Control Department. The main tasks of the Department are ticket control, including the timetable accuracy control, cleanness of the vehicle, tidiness of the traffic staff and the manner of their conduct towards the passengers, control of issuing and collecting payment for tickets, as well as passenger control with the purpose of determining legitimacy of their fare. A part of the Public Relations Department working at the Call Centre and 


\begin{tabular}{|c|c|c|c|}
\hline Joint Affairs Company & $\begin{array}{c}\text { Traffic Management } \\
\text { Company }\end{array}$ & $\begin{array}{l}\text { Public Passenger } \\
\text { Transport Company }\end{array}$ & Commercial Company \\
\hline Management Office & Managing Director's Office & Managing Director's Office & Managing Director's Office \\
\hline $\begin{array}{l}\text { Strategic Development And } \\
\text { Projects }\end{array}$ & Traffic Department & Traffic Department & Parking Department \\
\hline
\end{tabular}

\begin{tabular}{|c|c|c|c|}
\hline Joint Departments & $\begin{array}{c}\text { Road Maintenance } \\
\text { Department }\end{array}$ & $\begin{array}{c}\text { Maintenance Arrangement } \\
\text { and Control Department }\end{array}$ & $\begin{array}{c}\text { Commercial and Payment } \\
\text { Control Department }\end{array}$ \\
\hline
\end{tabular}

\begin{tabular}{|c|c|c|c|}
\hline $\begin{array}{c}\text { Finances and Controlling } \\
\text { Department }\end{array}$ & Joint Affairs & Joint Affairs & $\begin{array}{c}\text { Vehicle Maintenance } \\
\text { Department }\end{array}$ \\
\hline
\end{tabular}

\begin{tabular}{|c|}
\hline Procurement Department \\
\hline Internal Audit \\
\hline
\end{tabular}

\begin{tabular}{|c|c|c|}
\hline Supporting Departments & Public Utility Activity & Commercial Activity \\
\hline
\end{tabular}
Image 4 New macro-organization of the joint affairs company, traffic management company, public transport company and commercial company

Source: The Boston Consulting Group Servicing LLC: Završni elaborat projekta: "Izdvajanje komercijalne djelatnosti i potpornih funkcija iz KD Autotrolej” (Final study of the project: "Extracting commercial activities and supporting functions from the public utility company Autotrolej"), Rijeka, 5 December 2014

providing timely information to the users was also transferred to the same Department.

Other affairs of the Commercial and Payment Control Department include management and coordination of the sales and marketing affairs, participation in preparing sales contracts for the company and external service users in compliance with positive legal relations, providing maximum income for the Company and external users, both in regular and extraordinary activities (extraordinary transport, advertising on and in buses, selling secondary raw materials, office space rental...) and prescribing policy and guidelines for ticket control and traffic staff control, as well as monitoring implementation thereof. Extracting support functions and extracting support activities from the initial companies enables better and superior use of human knowledge and their expertise, reducing expenses and encouraging operative efficiency.

Separating the public utility and commercial activities enables improvement of cost transparency and compliance with EU legislation and practice according to which public utility companies should not perform commercial business activity. Separating the activities also enables further development of commercial services through increased focus and achievement of income synergies. Moreover, separating non core activities shall provide greater focus on the core activity, which should, in the long-run, result in increased accuracy, as well as the quality of the public passenger transport service, i.e. increased transparency and greater cost-effectiveness of the core activity. Centralising support functions shell enable uni- fied quality of service for all city companies and doubling of individual support functions shall be eliminated. In this manner, the foundation is set for development of an efficient central service centre, which is a precondition for the future integrated transport services.

\section{Structure of Integral PPT Model}

The procedure of reorganization and operationalization of the future Public Passenger Transport (PPT) model is an iterative procedure and modification of its structure must be enabled by an iterative procedure. Integral model is founded on the premise that iterations continue on one another with legal measures, and in this doctor's thesis the graphic display method was used. A suitable description of the integral PPT model in the area of the town of Rijeka and its hinterland gravitating in a polycentric manner is that it is a form of a real or physical system which intends to include significant characteristics of the system as simply as possible, with possible mathematical solution for understanding, optimisation, foreseeing the behaviour and management of the system. Traffic demand models describe legality and relations between the volume and characteristics of the traffic demand on one side, and activities of the traffic system on the other. Integral models are used in the planning procedure partially for analysis, but mostly for prognosis. Selection of public transport is the fundamental issue in planning of expending the existing one, or in constructing a new form of urban public transport system (the so-called modal SPLIT). Configuration 
of transport parameters does not determine only technological, operative and network-related properties of the system, but it also defines the role the public transport system has or shall have in the appearance of the city, its economic activities, social and environmental conditions. When preparing the integrated model developed for the needs of the said thesis, the following steps must be taken:

- extending, shortening or removing the existing lines from the traffic network

- planning new locations of the stops, especially at transfer points

- expand the existing network

- determine new corridors (main and auxiliary).
The initial premise starts from the known location of the lines, i.e. from the determined corridors within which the lines will be located. The line routes are determined based on minimised population (number of users) gravitating towards that line, while the corridor network is determined based on the analysis of the current status of the max. observed traffic loads during peak loads. Here, it is possible to change the idea of a corridor determined in advance, due to sufficient amount of relevant information concerning the main traffic flows in the city and through the city, which is a logical conclusion in the process of bringing a decision. In general, optimisation of new PPT network modalities is a very complex procedure, due to the need to satisfy market orientation, restructure opera-

\begin{tabular}{|c|c|}
\hline INTEGRATED PPT OFFER MODEL \\
\hline ANALYSIS OF THE ENVIRONMENT \\
\cline { 1 - 1 } ADOPTING INITIAL CRITERIA & BUS TRANSPORT \\
& CITY RAILWAY \\
\hline
\end{tabular}

\begin{tabular}{|c|c|}
\hline \multicolumn{2}{|c|}{$\begin{array}{c}\text { EXISTING MODEL } \\
\text { (current status of the system) }\end{array}$} \\
\hline \multirow{3}{*}{$\begin{array}{c}\text { System of } \\
\text { monitoring } \\
\text { and analysing } \\
\text { traffic flows of } \\
\text { passengers and } \\
\text { goods }\end{array}$} & $\begin{array}{l}\text { Criteria weight } \\
\text { relations }\end{array}$ \\
\hline & $\begin{array}{l}\text { Characteristics of } \\
\text { alternatives }\end{array}$ \\
\hline & $\begin{array}{c}\text { Evaluation of } \\
\text { alternatives }\end{array}$ \\
\hline \multirow[t]{3}{*}{$\begin{array}{l}\text { Travel origin and } \\
\text { destination matrix }\end{array}$} & Initial model \\
\hline & CORRELATION \\
\hline & $\begin{array}{l}\text { BETWEEN THE } \\
\text { SELECTED }\end{array}$ \\
\hline $\begin{array}{l}\text { Application of ITS } \\
\text { methods }\end{array}$ & $\begin{array}{c}\text { MODEL AND } \\
\text { INDIVIDUAL } \\
\text { ALTERNATIVES }\end{array}$ \\
\hline
\end{tabular}

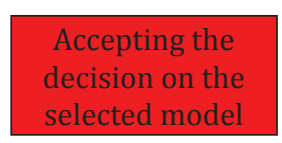

\section{RESEARCH ALGORITHM}

NEW SOLUTIONS (testing)

\section{Method} selection

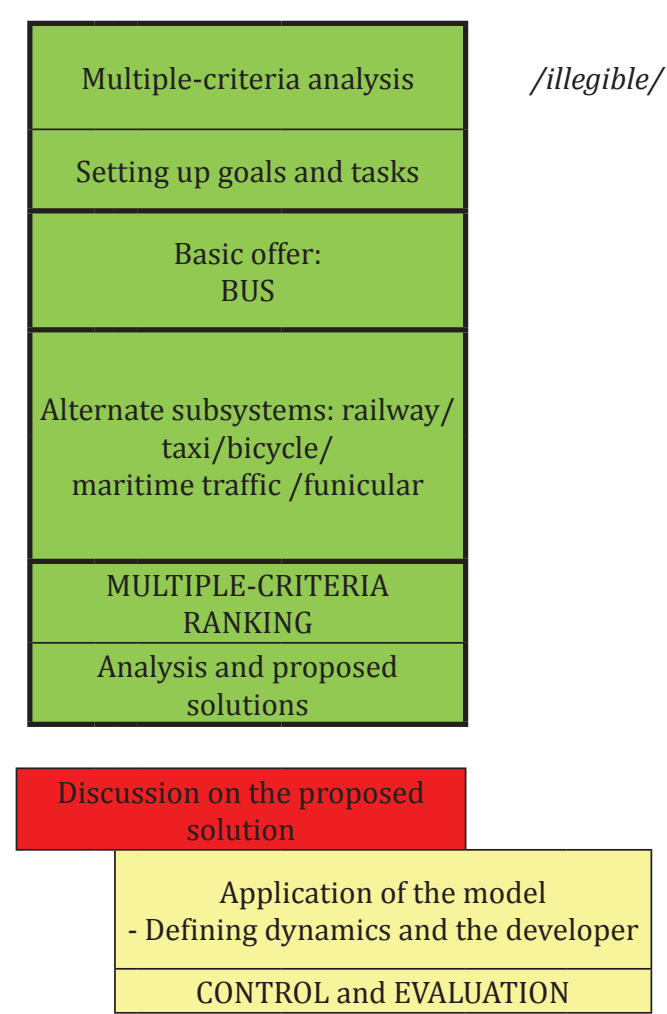

Image 5 Integrated PPT model

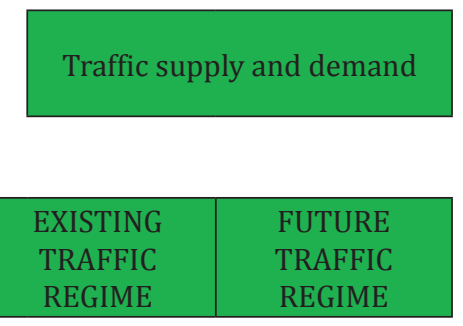

SIMULATED FINANCING

\section{/illegible/}




\begin{tabular}{|c|c|}
\hline STRENGTHS & WEAKNESSES \\
\hline $\begin{array}{l}\text { - higher level of traffic safety, less traffic accidents - public } \\
\text { transport is considered the safest form of transport for } \\
\text { mobility of people in cities } \\
\text { - less specific energy costs compared to individual traffic } \\
\text { - less pollution of air and water - public transportation vehicles } \\
\text { are smaller polluters per passenger then personal cars, which } \\
\text { have an average occupancy of less than } 50 \% \\
\text { - noise decrease }\end{array}$ & $\begin{array}{l}\text { - poor traffic infrastructure influences the increased expenses of } \\
\text { fleet maintenance } \\
\text { - insufficient incentives for ecologically acceptable vehicles - } \\
\text { CNG bus introduction programme requires better dynamics } \\
\text { and realisation } \\
\text { - } \text { city road network overload with partial horizontal separation } \\
\text { for PPT vehicles } \\
\text { - } \text { strategic development of PPTs with too slow realisation of } \\
\text { extension of traffic infrastructure planned by the previous } \\
\text { urban plans } \\
\text { - small commercial speed at endpoints of PPT network (suburban } \\
\text { transport) }\end{array}$ \\
\hline OPPORTUNITIES & THREATS \\
\hline
\end{tabular}

Image 6 SWOT analysis of PPT

tive expenses and justify new, capital investments. For economic reasons, the services must be defined in the package of lines and frequency, or in timetables. Optimisation of the urban public transport system is usually performed via models (Image 6): when analysing travelling time, adjusted timetables will have priority, and the schedules of different lines do not have to be in compliance in each case. Qualitative assessment of the solution is proven by an algorithm based on the calculation of the total dynamic moment of the urban complex segment pursuant to the public transport charted network. Therefore, it is necessary to synthesise the obtained results in the manner to analyse the sensitivity of the solution to changes of parameters, and if possible and necessary, also to the changes of criterion variables. After the procedure of evaluating the comprehensive solution has been completed, the adopted data shall be entered into the GIS database. Modelling of PPT in the city of Rijeka implies the application of a multicriterial decision-making, whereat numerous qualitative and quantitative criteria must be evaluated. However, deviations from ideal, scientifically determined facts are often possible in practice.

Integration in public urban traffic, founded on several theoretic facts, justifies its vision from the viewpoint of efficient use of resources and as a result it creates an "optimum" combination of PPT. The elements used are, e.g. efficiency of inventory number of vehicles from the perspective of the entire system, i.e. the possibility of introducing new transport forms (such as city rail and maritime transport). By introducing such forms of transport attractiveness is increased for the passengers (regularity, attractiveness, comfort, travelling frequency, greater capacity and speed). However, such an approach has a clear relationship with microeconomic approach when other components must be taken into account, additional passenger expenses, etc.

The structure of integral PPT model implies upgrade of the existing one, i.e. a proposal of construction of the new PPT system (the so-called Modal SPLIT).

Integral model in operation implies:

- Extending, shortening or removing the existing lines from the traffic network

- Planning new locations of stations (in transport points)

- Expansion of the existing network

- Determining night corridors.

A graph drawing method is the second step in implementation of PPT integration, i.e. optimisation of the comprehensive system via an algorithm which includes calculation of the dynamic moment of the segment of urban and suburban transport.

\section{Paradigms and Dilemmas of Integration of PPT Subsystem Into the Integrated Public Passenger Transport Model}

The primary goal of the integrated PPT model, from the viewpoint of efficient use of resources i.e. capacities of the means of transport, is to establish optimum logistic network of transport modules with various traffic and technological parameters. In doing so, special attention must be paid to the efficient collection of payment for transport services in the context of forming a new institutional holder, i.e. a "transport alliance". Selection of individual transport modality, especially in relation of: bus - city railway, shall be funded on minimising travelling time and on travelling comfort. Subjective perception of new, alternative subsystems 
i.e. railway, funicular and maritime transport, is not subject to quantification. Therefore, it is difficult to include it in the multicriterial analysis. Concerning the previously stated facts on the mentality of the local population and long-term habit of using road transport, this phenomenon should be researched as a social paradigm in the future.

The PPT model based solely on bus subsystem may evolve only in the long run. Substitution and extension of city and regional passenger services is an unstopable trend in Europe and the world, and it is subsidised either from local sources or from European funds. On the example of the City of Rijeka and its immediate surroundings, there is a mitigating factor, an almost ideally laid route of the current railway tracks. Penetrating the most densely populated city zones, especially its centre, its most active zones, such a route, in the first implementation phase, enables simple interpolation of the local traffic running on the existing single-railed track into the railway timetable. In the later phase, there is an option of reconstructing the single-railed track into a double-track rail. Concerning the topographic properties of the PPT intervention area, it is realistic to expect satisfaction of traffic demand up to $1 / 4$ of the total traffic demand in the longitudinal corridor. Out of the total transport effect, further 1 to $2 \%$ would be attracted to funicular Trsat, with a hypothetical division into layered structure of the travelling motivation: business, educational, religious, tourist and recreational, etc. The maritime component of the integral PPT model would be realised by supplying relevant lines at sea. Therefore, the starting point and the destination point on the route Opatija - Preluk to Pećine, with a range of jetties in between, would be connected locally, and in the wider sense in the zone of Rijeka Bay, i.e. the entire Kvarner. The said maritime transport component, as well as bicycle service on the land, should be provided with an attribute of recreational and tourist upgrade, which would result in the city of Rijeka, with its gravitating hinterland and its maritime zone, gaining a recognizable and attractive integral transport service for all categories of the local population, but also for tourist clients, which has already recorded increased natural and financial indicators.

Along with all of the arguments listed above, expected support from EU funds should not be neglected when it comes to introducing ecologically acceptable modalities of public transport, from CNG buses to rail transport. In that manner, it is possible to compensate the expected high expenses of the initial investment and, most of all, the economically unsustainable financial structure. Historically, many transport technologies were economically unjustifiable investments at the beginning, and they subsequently proved their sustainability and unquestionable efficiency manifested by high quality of service.

\section{Conclusion}

Rational use of space and other resources for traffic purposes is a very significant factor in planning and designing urban agglomerations. Integrating the PPT traffic subsystems is one of the few solutions which can resolve the previously listed dubiosities. The guiding principle of the said paper is the selection of the optimisation algorithm based on application of heuristic or metaheuristic methods, due to a large number of potential solutions, where such methods were competitive compared to exact methods. The conclusion that planning itinerary of the future traffic lines of integrated PPT in the City of Rijeka presumes a comprehensive evaluation of the number of potential users in the area of the gravitational intervention, with achieving the so called "desire lines grid" is indisputable. The hypothesis of the said thesis may be sublimated by answering two questions: What are the traffic and technological parameters of the proposed modalities/subsystems of the integral PPT, and to what extent is it possible to transform the user mentality in changing the acquired habits (especially in accepting the railway transport offer)? By combining an approach based on engineering and sociology, it is possibly to claim with much certainty that changes of the PPT model in the City of Rijeka with the accompanying hinterland are inevitable. It is proven historically that the city government with the accompanying institutions must recognize the turning point in managing PPT policy and provide competent answers to the ever-increasing criteria of this specific segment of the social norm. Institutionally speaking, the first step of PPT integration requires founding regional traffic management. Financial support shall be a surmountable component if local and regional self-government units, lead by the city administration, continue with subsidies policy. The complete project shall be technologically and operatively realised by the main developer of the comprehensive transport service, a kind of a "transport alliance". A revised concept of the new organisational model of city companies implies interaction between public utility and commercial companies, influencing the city policy of transforming all public services for customers. Based on promotion of the so-called urban mobility via assets received from EU funds, a problem of economic sustainability of the integrated PPT model shall be resolved.

\section{References}

[1] Baričević, H., Poletan-Jugović, T., Krpan, LJ., Šuperina, V.: "Prostorno-prometna integralna studija Primorsko-goranske županije i Grada

[2] Chien, S., Yang, Z., Hou, E.: “Genetic algorithm approach for transit route planning and deisgn", ASCE Journal of Transportation Engineering, Vol. 127, No. 3, 2001.

[3] Gibbs, D., Krueger, R., MacLeod, G.: "Planning smart city regions in an age of market - driven - urbanism", 2013.

[4] Krpan, Lj., Baričević, H., Maršanić, R.: "Quality municipal public passengers transport as response for dependence on the car", Automatizacija u prometu, Korema, Zagreb/Istanbul, 2010.

[5] Smojver, Ž., Baričević, H., Janjatović, J.: "Podizanje kvalitete života u urbanim aglomeracijama kroz razvoj javnog prijevoza putnika (osvrt na grad Rijeku)", Automatizacija u prometu, Korema, 2014. 
[6] Smojver, Ž., Mrvčić, R.: "Uvođenje UNP tehnologije u Komunalno društvo Autotrolej", Automatizacija u prometu, Korema, 2014.

[7] Vuchic, V. R.: "Urban Transit - Operations, Planning and Economics", Jon Wiley \& Sons, New Jersey, 2005.

[8] Smojver, Ž.: "Model integriranog javnog prijevoza putnika u Gradu Rijeci", doktorska disertacija ("Integral Model of the Public Passenger Transport in the City of Rijeka", doctor's thesis), Rijeka, 2017.
[9] The Boston Consulting Group Servicing LLC, Završni elaborat projekta: "Izdvajanje komercijalne djelatnosti i potpornih funkcija iz KD Autotrolej" (Final study of the project: "Extracting commercial activities and supporting functions from the public utility company Autotrolej"), December 2014.

[10] AT Kearney: Analiza poslovanja i podizanje razine usluge gradskog prijevoza i prometa (Business Operation Analysis and Improving the Level of Urban Transport and Traffic Services), Rijeka, 27 June 2014. 